\title{
ID2 wt Allele
}

National Cancer Institute

\section{Source}

National Cancer Institute. ID2 wt Allele. NCI Thesaurus. Code C52123.

Human ID2 wild-type allele is located in the vicinity of 2 p25 and is approximately $5 \mathrm{~kb}$ in length. This allele, which encodes DNA-binding protein inhibitor ID-2, is involved in both transcriptional repression and cellular proliferation. 